\title{
The Croatian Catholic Church Since 1990
}

\author{
SABRINA P. RAMET
}

\section{I}

Throughout the existence of Yugoslavia the Roman Catholic Church was always made aware that it was a minority Church. Already in the Kingdom of Yugoslavia the Church was unable to obtain a concordat even though the Vatican had obtained similar concordats with most other European governments. Later, after the Second World War, the communist government used the fact of fascist collaboration by a certain sector of the clergy to tarnish the entire Church, even though both the Vatican and Archbishop Stepinac had spoken out during the war to criticise the involvement of Catholic priests within the Ustaša and - at least on Stepinac's part - to condemn Ustaša policies of genocide and expulsion.' Much later, after the election of Karol Wojtyla to the papacy in 1978, despite the strong desire on the part of Slovene and Croatian Catholics to receive their pontiff the communists repeatedly vetoed plans to invite John Paul II to the country. In old Yugoslavia - whether the Kingdom of 1918-41 or the socialist state of 1945-912 - the Roman Catholic Church was a minority church and was kept in a position of inferiority.

Although I have elsewhere explored the 'victim complex' of the Serbian Orthodox Church $^{3}$ the Catholic Church clearly occupied a position inferior to that of the Serbian Orthodox Church in the interwar kingdom, was attacked far more bitterly in communist Yugoslavia than was the Serbian Orthodox Church or the Islamic community, and was from time to time painted as an 'Ustă̌a Church'; neither the Serbian Church nor the Islamic community suffered any comparable indignity.

Under such circumstances the Catholic Church could only breathe a sigh of relief when socialist Yugoslavia broke up. Whatever we might conclude about the benefits and liabilities of socialist Yugoslavia, and about the merits and demerits of its dissolution, from the standpoint of the Catholic Church and Vatican interests the breakup of multiconfessional Yugoslavia was virtually an unmixed blessing. It was therefore no surprise that the Vatican was one of the first states to extend diplomatic recognition to the new Croatian state in 1991.

In the days of the Socialist Federative Republic of Yugoslavia (SFRY), the Croatian Catholic Church maintained a presence not only in Croatia but also in Bosnia, in Serbia proper (principally in Belgrade) and in Vojvodina. The number of Croats 
living in Serb-controlled regions (whether under Milošević or under Karadžić) declined steadily after 1987, the year in which Milošević came to power in Serbia. Between 1987 and 1993 the number of Catholics living in the Archdiocese of Belgrade declined from 34,000 to between 8000 and $9000 .{ }^{4}$ Figures in Bosnia are even more drastic. According to the Süddeutsche Zeitung more than 150,000 Catholics were driven from their homes by Serbian forces between April 1992 and May 1995 alone. ${ }^{5}$ Moreover, in May 1995 Bosnian Serbs renewed their expulsions of Catholics and Muslims and in the succeeding four months expelled about 22,000 Catholics from areas of northwestern Bosnia under their control. ${ }^{6}$ Of the 180,000 Catholics who had inhabited the archdiocese of Banja Luka in 1991 only 7000-8000 remained as of mid-October 1995. ${ }^{7}$ In the city of Banja Luka itself, where some 20,000 Croatian Catholics were living in 1991, only 3000 Catholics remain today. ${ }^{8}$

The trials of transition have been accompanied at the same time by the opening of new opportunities. Already on the eve of Croatia's first multiparty elections (conducted in April 1990) the Catholic bishops issued a statement which, while on the face of it abjuring political advice, nonetheless made clear the Church's preference for parties of the right. 'Specifically', the statement read,

it matters whether the Church will finally gain public legal status or whether a more or less skillfully formulated law on the legal position of religious communities and of the same community, i.e. citizens who are believers, will be kept under surveillance, controlling their development and activity as if they were a potential social danger. ${ }^{9}$

Presidential candidate Franjo Tudjman had already stirred some concern during the election campaign by exploiting a less than committal letter from Cardinal Kuharić to suggest that his party, the Croatian Democratic Community (HDZ), had been endorsed by the Church. The Church protested against this misrepresentation, but that exchange notwithstanding, the Church was pleased to see the communists voted out of power and replaced by a right-of-centre party. One of the first decisions taken by newly elected President Tudjman was to allow the Catholic Church to organise religion classes in state schools. In spite of reservations expressed by some clergy, who feared that state backing could weaken Catholicism, the hierarchy accepted the offer and the first religion classes were introduced as early as the autumn of that same year. ${ }^{10}$ Meanwhile in June 1990, in neighbouring Bosnia-Herzegovina, Catholic prelates raised a demand that the legal proscription of the formation of associations based on religious affiliation be stricken from the books, and encouraged Bosnian Catholics to organise themselves along religious (and hence national) lines." The Catholic Church also entered into discussions about legal guarantees of abortion in the republic, ${ }^{12}$ while Anto Baković, a Roman Catholic priest, set up the so-called Croatian Population Movement, for the purpose of stigmatising childless couples, combatting abortion, preventing the emigration of young women of child-bearing age and promoting the concept of four-child families. ${ }^{13}$ Despite this record, Ivan Miklenić, editor of the Catholic weekly newspaper Glas koncila, told a Danas journalist in 1994 that 'our Church has up to now not demanded anything ...'. ${ }^{14}$

The introduction of religion classes was initially to some extent circumscribed by the impediments created by the war and by the question of the availability of qualified teaching staff. During the 1991-92 school year about 50 per cent of school children (ages 6-14), or about 65 per cent of school children from Catholic families, were enrolled in religious instruction, but already by the following year religious 
instruction was dramatically expanded and assumed a regular and stable place in elementary and middle schools throughout the republic. ${ }^{15}$ Reviewing the situation two years later the Commission for Relations with Religious Communities declared the programme (of restoring religious instruction) a success. ${ }^{16}$ In theory Catholic religious instruction was not obligatory and required the assent of the parents, ${ }^{17}$ but although some 76 per cent of the republic's population is Catholic, ${ }^{18}$ problems soon appeared where children from among the other 24 per cent were concerned.

Of these about half were Serbs, and for them the spectre of Catholic religious instruction appeared anything but innocent. Quite apart from the threat that such instruction posed to the preservation of Orthodox belief among Serbian children, it also revived memories of the forced conversions to Catholicism in Pavelić's Croatia 50 years earlier. P.B., a 36-year-old Serbian engineer who eventually fled from Croatia, recounted his family's frustrations with Croatia's socially-enforced, if technically optional, religious instruction:

My daughter enrolled in the first grade. She had to say whether she was going to take religion or not. How can you say that you do not want to, when I had seen how a Croatian family in Velika Gorica had suffered, people who were simply atheists, but they had to move because their children were mistreated by other children? And then, what could we do but say: She will take religion! ... Then they adopted rules to the effect that children must attend weekly masses. This is monitored by the religion teacher. They took special satisfaction in putting the Serbian children in the choir to sing in the service on the Catholic Christmas Eve. ${ }^{19}$

In Zagreb and Osijek teachers were said to have told their pupils that children who did not attend religion classes were sentencing themselves to be considered “Cetniks ${ }^{20}$ - an interesting suggestion, insofar as it reveals the intolerance latent in overenthusiastic religious proselytism. Under these circumstances, Orthodox believers and clergy fled from Croatia. Orthodox priests fled their dioceses and, reportedly, by 1993 not a single Orthodox priest remained in Split, Sibenik or even Zadar, once a major centre for Croatian Serbs. ${ }^{21}$

As the stories of sundry Serbian and other non-Catholic families became better known, democratically-minded Croats became concerned. In November 1994 Franjo Cardinal Kuharić belatedly sent a letter to parishes throughout the republic requesting that they provide information as to how many non-Catholic children were attending Catholic religion classes, how many were from mixed marriages, how many from solely Serbian marriages, and whether Orthodox children were being rebaptised into the Catholic Church. Feral Tribune characterised this letter of Kuharic's as '... the most courageous letter bearing the cardinal's signature published in recent times, because it "proceeds from the assumption that conversions to Catholicism are a fact and that it is necessary to investigate how they occurred and how many have taken place"., ${ }^{22}$ Three months later Cardinal Kuharić received Jovan Pavlović, Serbian Orthodox metropolitan of Zagreb and Ljubljana, for a two-hour discussion in which, among other things, the subject of allegations of the conversions of Orthodox children to Catholicism came up. Following the talks Metropolitan Jovan released a statement indicating that he had 'no concrete data' about the rebaptising of Serbian children but that the two prelates would need to sit down again shortly to decide on concrete steps to correct the problem. ${ }^{23}$ 


\section{III}

Interestingly enough, instead of scrapping the communist infrastructure for monitoring religious organisations and activities - an infrastructure whose existence the Church has always resented - Croatia's postcommunist leaders merely redesigned it, fashioning a new 'Commission for Relations with Religious Communities' which has from time to time held meetings with the 'Commission of the Croatian Bishops' Conference..$^{24}$ Even more surprising, surely, to any who expected that the passing of communism might open up an era of church-state mutual admiration and amity has been the sheer extent of differences between ecclesiastical authorities and the new state authorities. Croatian bishops, for their part, have expressed dissatisfaction with the limited influence they have had on policy and have called for a greater church role in the political sphere. ${ }^{25}$ Among state authorities there have been those who have expected the Church to restrict itself to administering the sacraments, performing benedictions and engaging in Biblical exegesis, ${ }^{26}$ alongside others who have wanted to treat the Church as 'their' Church, transforming church-state relations into something along the lines of caesaropapism. ${ }^{27}$

The Church has repeatedly criticised the Tudjman government for human rights violations, has demanded more tolerance in both religious and ethnic relations, ${ }^{28}$ and in March 1995 organised a two-day conference on 'The Church, Democracy and General Welfare in Croatia', at which participants pointedly emphasised the centrality of human rights and respect for people of all ethnic backgrounds (i.e. including Serbs) to any would-be democratic society. ${ }^{29} \breve{Z}$ ivko Kustić, the fiery director of the Catholic Information Agency for Croatia, went further and was quoted in the 28 March 1995 issue of Novi list as saying that some Croatian nationalists had embraced a form of Nazism. ${ }^{30}$ 'In a bar in Zagreb', Kustić continued, 'I saw a sign reading "No admittance to Serbs". This is a stab into the heart of democracy ... . In Croatia, there are even official newspapers of neo-fascist and neo-Nazi parties with the following motto below their names: "Damned be Serbs, Muslims and Jews, wherever they are"..31

Tudjman has reason to reflect. The prestige of the Catholic Church in Croatia has never been higher. In a September 1994 poll conducted by the Zagreb weekly Globus, Cardinal Kuharić (born 1919; archbishop of Zagreb since 1969) was ranked the most respected person in Croatia, with 30.7 per cent of respondents identifying him as 'most respected by Croatian citizens'. President Tudjman trailed in second place, with 21.6 per cent. At the same time, asked which archbiship of Zagreb Croats most respected, Kuharić was again placed first, garnering 39.1 per cent of responses; Cardinal Stepinac (1898-1960; archbishop of Zagreb 1937-60) emerged in second place with 30.6 per cent, leaving third-place Franjo Šeper (1905-81; archbishop of Zagreb 1960-9) far behind, with 2.7 per cent. ${ }^{32}$

As early as April 1992 the Catholic Church found itself under attack by members of Croatia's ruling party. Neven Jurica, one of the HDZ's leading members, accused the Catholic weekly Glas koncila of being pro-Yugoslav, while Hrvoje Sosic, another HDZ member, was said to have characterised former Glas koncila editor Živko Kustić as being an unreformed communist. ${ }^{33}$

It is within this context that one must assess the significance of the dispute between Croatian bishops (above all, Cardinal Kuharić of Zagreb and Archbishop Vinko Puljić (born 1945), later elevated to the College of Cardinals) ${ }^{34}$ and the Tudjman government that developed in summer 1993. Having repeatedly called for ethnic tolerance ${ }^{35}$ Kuharic quickly distanced himself from the partition policy being 
pursued by Tudjman and his lieutenant Mate Boban, then leader of the Bosnian Croats, in Bosnia-Herzegovina, and joined Sarajevo Archbishop Puljić in championing the preservation of the territorial integrity of a sovereign Bosnia-Herzegovina. Most of the lower clergy endorsed their bishops' stance, contributing to a growing rift between Croatian authorities in both Croatia and Bosnia and the Catholic Church. ${ }^{36}$ Cardinal Kuharic denounced the destruction of Serbian churches in Croatia, ${ }^{37}$ while Archbishop Puljić worked quietly, behind the scenes, to foster a reorientation of Croatian policy from confrontation with the Muslims to collaboration. ${ }^{38}$

It is thus scarcely surprising that Cardinal Puljic shared the international peace prize 'Together for Peace' with retired archbishop of Vienna Franz Cardinal König in 1995. ${ }^{39}$ On the other hand, the Catholic Church has received no applause from Croatian state authorities, and in May 1995, concerned about the continuing rancour between church and state in Croatia, the Holy See invited both sides to send representatives to Rome for talks. On 18 May Croatian deputy prime minister Jure Radić and the bishop of Krk Josip Božanić left for Rome for meetings with senior Vatican officials. Radić's office released a statement to the effect that 'these talks are expected to promote the development of harmonious relations between the Republic of Croatia and the Holy See, and contribute to the process of defining the relations between church and state [in Croatia]. ${ }^{40}$

\section{IV}

One of the specific features of the Serbian Insurrectionary War of 1991-95 has been the way in which all three sides, but most especially the Serbs, have systematically targetted the churches and sacral objects of other faiths for destruction. For the Catholic Church, the losses have been nothing short of catastrophic. As early as March 1992117 Catholic sacral objects in the Franciscan Province of Split had been destroyed or seriously damaged, accounting for one third of the Church's spiritual and artistic heritage in the province. ${ }^{41}$ By June 199445 per cent of Catholic churches in the Vrhbosanska-Sarajevo archdiocese had been destroyed, and another 30 per cent had been seriously damaged. In the archdiocese of Mostar 40 churches and sacral objects were reduced to rubble in the same period. In the diocese of Banja Luka 50 per cent of churches or sacral objects were reduced to ruin in the same period, while another 45 per cent were severely damaged..$^{42}$ And in the so-called Krajina, during their four-year occupation, Serbs blew up or tore down 125 Catholic buildings and heavily damaged another 30 holy sites. Only six of the original 161 Catholic sacral objects in this Serb-occupied region escaped with only slight damage. By contrast, of the 121 Serbian Orthodox churches in the region prior to the war, only three had been destroyed as of October 1995, with another two seriously damaged - graphically revealing that the destruction of Catholic churches was the result of premeditated and systematic policy, rather than the random outcome of battles and field action. ${ }^{43}$ Under the circumstances, many Orthodox parishes have lost both their priests and their parishioners, contributing to the result that of the 210 active Orthodox churches in pre-war Croatia only 15 functioning Orthodox churches remain today. ${ }^{44}$

In spring 1995, as the newly armed Croat-Bosnian Army went on the offensive, Bosnian Serb authorities in Banja Luka again started blowing up Catholic churches and expelling non-Serbs. Within a matter of weeks Bosnian Serbs destroyed six Catholic churches within the city limits of Banja Luka and murdered two Catholic 
priests, one nun and several lay Catholics. ${ }^{45}$ Bishop Franjo Komarica of Banja Luka was placed under house arrest (on 4 May 1995), while a number of monks and nuns were driven from their homes. ${ }^{46}$ In protest against these actions and against the Serbs' self-proclaimed intention of eliminating all traces of Catholicism from the city, 46year-old Bishop Komarica began a hunger strike on 18 May, a few hours before the Serbs dynamited their fourth church for the month. ${ }^{47}$ Komarica wrote two letters to Bosnian Serb leader Karadžić within the two succeeding weeks complaining of the wholesale expulsion of civilian innocents. ${ }^{48}$ Karadžić did not bother to answer. (Komarica was finally released from house arrest on 21 December 1995.)

Throughout the four-and-a-half years of war Croatian Catholic bishops made repeated statements protesting against violence and holding interfaith meetings with Serbian Orthodox, Muslim, Jewish and Evangelical representatives. ${ }^{49}$ They have deplored ethnic hatred and urged reconciliation and dialogue between the warring parties. In June 1995, Cardinal Kuharić received Tadeusz Mazowiecki, the director of the UN Commission for Human Rights, to discuss the status of human rights on the territory of the republics of Croatia and Bosnia. ${ }^{50}$

But when Croatian forces liberated inner Croatia and the Dalmatian hinterland (the old 'Vojna Krajina' or 'Military Frontier', as the Habsburgs designated it; the 'Krajina' as today's Serbs have called it) in August 1995 and reports began to circulate about Croatian atrocities against Serbian civilians in the region, Cardinal Kuharić at first defended the Croatian government. Weighing the conflicting reports and on the basis of the information he then had at his disposal Kuharic concluded that fleeing Serbs had left at the instigation of their own civil and ecclesiastical leaders. In an official statement Kuharić declared:

The fact is that Croatia liberated its territory so that 117,000 expelled Catholic Croats could return. But it is also a fact that the Croatian government did not want the Croatian citizens of Serb nationality to leave their homes. An appeal by the president of the republic to the citizens of Serb nationality, guaranteeing them all rights, freedoms and security and asking them not to leave their homes, was repeated continually. However, I very much regret that people left despite all guarantees .... .

As more reliable documentation became available, however, Kuharić felt the need to correct the record. On 1 October, addressing an open-air mass for 3500 soldiers and officers at Marija Bistrica, Cardinal Kuharić reviewed the evidence and condemned the killing of Serbian civilians and looting and house-burning by Croatian forces. ${ }^{52}$ But if the hatred (on all sides) and desire for vengeance (on the Croatian side) could not very well be damned up, it could at least be understood. As Sarajevo's Cardinal Puljić put it in June 1995 (talking about the killing of peaceful Croatian Catholics and Bosnian Muslims), 'They were not combatants; their only crime was to be alive'. ${ }^{53}$

The first Catholic-Orthodox 'summit meeting' took place on 23 September 1992, at the suggestion of Patriarch Pavle of Belgrade. Conferring in Geneva, Cardinal Kuharić and Patriarch Pavle issued a joint message calling for an end to hostilities, emphasising the need to end the 'blasphemous and mindless destruction of both Christian and Muslim sanctuaries', the unconditional release of all POWs and hostages, an end to 'ethnic cleansing', the possibility for displaced persons to return 
to their homes, the restoration of unobstructed communications, transport, and movement between the republics, and the termination of all encumbrances to the dispatch of humanitarian aid..$^{54}$ Later, on 17 May 1994, Cardinal Kuharić signed a declaration with Patriarch Pavle and Patriarch Aleksi II of Moscow calling for peace and condemning the exploitation of religious differences to foment hatred. ${ }^{55}$ But despite these and other signs of ecumenical intentions distrust has run deep and even appeals for peace have proven capable of igniting tempers. An example is the appeal for peace issued jointly by the Catholic bishops of Croatia and Bosnia at the end of 1994 . The Serbian Orthodox Church, far from being pleased with the appeal, condemned it as 'one-sided and egoistic', and claimed that it followed the lines of Croatian 'war propaganda'. 56

But interconfessional distrust and hatred are only one side of the coin. The other side of the coin is religious self-congratulation tending toward messianism. If the convictions of a group's leaders are any guide, then at least some Bosnian Serb forces have surely been inspired by some degree of messianism. Talking to a journalist from the Montenegrin journal Svetigora in early 1995, Karadžić revealed his belief that the 'complete restoration of the Serb empire' was 'God's will'. Said Karadžić: 'I am convinced that God will show me which way to take and what to do. And that will certainly be good .... ${ }^{.57}$

Tudjman's HDZ, which naïvely restored the medieval currency system which the fascists had earlier restored, which naïvely restored the 1000-year-old chequerboard Croatian coat-of-arms despite the fact that the fascists had also used these insignia, and which rather foolishly moved all at once to redress the decades-long over-hiring of Serbs in the Croatian police forces, also acted clumsily in matters of religion. The reintroduction of Catholic religious classes in state schools has already been mentioned. But to that one must add the announcement, by the Croatian parliament as early as January 1992 that it planned to nullify the 1946 trial of Cardinal Stepinac on charges of collaboration with the Ustaša. The Serbian Orthodox Church reacted immediately criticising the decision. ${ }^{58}$ Although the trial of Stepinac was a complete mockery of justice, with no point of contact with reality, and although the charges of collaboration were fabrications designed to obscure the real reasons for the communists' desire to imprison Stepinac - his refusal to become a pliant and servile tool of the communist regime ${ }^{59}$ - it was surely unwise for the Tudjman government to nullify the trial by fiat, without bringing forth the evidence. Moreover, the Church's repeated hints that the canonisation of Stepinac is only a matter of time only serve further to estrange Serbs who were all too ready to accept the communists' line on Stepinac.

In December 1995 the Belgrade daily Politika reported that efforts were afoot to force the remaining Serb Orthodox parishes in Croatia to reconstitute themselves as a Croatian Orthodox Church. ${ }^{60}$

\section{VI}

Cardinal Kuharić turned 77 years old in April, but at the time of writing no decision has been taken regarding his eventual successor. Sarajevo's archbishop, Vinko Cardinal Puljić, may well be the front runner for the succession, as the Zagreb weekly Globus has suggested. ${ }^{61}$ But there are other candidates, among them three professors at the Faculty of Theology - Josip Baloban, Antun Škorčević and Matija Breljak - not to mention Stjepan Kožul, director of the Diocesan Museum in Zagreb. The importance of the episcopal succession is only accentuated by the Tudjman government's all-too-evident interest in obtaining influence in Kaptol. In fact, the 
Croatian Catholic Church showed some serious internal divisions during the Serbian Insurrectionary War. Whereas Kuharić, Puljić and Komarica preached moderation and took a firm stance against nationalist intolerance, many of the lower clergy, especially on the territory of Herzegovina, adopted explicitly nationalist positions. ${ }^{62}$ Catholic parish priests in both Croatia and Bosnia-Herzegovina have regularly used the pulpit to convey overtly political messages, according to a report in Globus, including advising parishioners on how to vote. In Kiseljak and other communities local parish priests even made speeches at HDZ political meetings. ${ }^{63}$

But if many among the lower clergy have rallied to the HDZ banner, the hierarchy has remained aloof. There have been repeated 'summit meetings' between church hierarchs and government representatives, ${ }^{64}$ and though both sides have been rather reticent about the substance of these talks, it is an open secret that the government in Zagreb wants to obtain a written agreement covering such things as religious schooling, the army vicariate and the status of the clergy and of ecclesiastical institutions. ${ }^{65}$

In the early months of the Tudjman government there were some observers who believed that church-state relations in Croatia had turned the corner and that the distrust and mutual criticism of the communist era had given way to friendliness and mutual support in the era of nationalism. Although there was certainly some evidence to support this conclusion, ${ }^{66}$ and although there have been some concrete gains for the Church (such as the reaffiliation of the Faculty of Theology with the University of Zagreb in March $1996^{67}$ ), a more sophisticated reading would reveal that church-state differences have endured into the postcommunist era, even if their foci have inevitably changed. What is ironic, though, is that the Catholic Church, which used to articulate nationalist concerns in the face of the Tito regime's antinationalist programme (or 'internationalist', if one prefers the word), has more recently found itself thrust into the role of guardian of internationalism, in the face of the Tudjman government's nationalist programme. In a highly symbolic and indicative appeal Pope John Paul II, upon making his first visit to Zagreb, specifically offered a 'kiss of peace' to the Serbian Orthodox Church ${ }^{68}$ and exhorted his listeners that 'It is necessary to promote a culture of peace which does not reject a healthy patriotism but [which] keeps far away from the exasperations and exclusions of nationalism' ${ }^{69}$

The Church does not, of course, advocate nationalism pure and simple anywhere. What may be said is that the Church has its own specific view of nationalism and has always distinguished between healthy and unhealthy nationalism. It therefore had to defend 'healthy' nationalism from the Tito regime, just as it considers it incumbent upon itself to criticise what it considers 'unhealthy' nationalism. Nationalism, for the Church, is at its best a feeling for the collective good, and, insofar as it remains true to a correct understanding of what is good, may arguably inspire a nation for acts of nobility and virtue. But at its worst, nationalism sets the nation above the good, much as the religiosity of Abraham set God above the good (as shown in the story of God's command to kill Isaac). And when the good is sacrificed for national or religious self-interest the political agenda of a given society may become seriously warped. Fortunately, in the Croatian case at least, the Church has apprehended its duty to serve as a beacon of reason and moderation, and has acted in conformity with that apprehension.

\section{Notes and References}

See Aleksa Benigar, Alojzije Stepinac, Hrvatski Kardinal (Žral, Rome, 1974); and Richard 
Pattee, The Case of Cardinal Aloysius Stepinac (Bruce Publishing Co., Milwaukee, 1953).

2 Yugoslavia had actually already ceased to function as a unified state in 1989 and ceased to be socialist in 1990 . What occurred in 1991 was only the finalisation and formalisation of the breakup of the country.

3 See my 'The Serbian church and the Serbian nation', in Sabrina P. Ramet and Ljubiša S. Adamovich (Eds.), Beyond Yugoslavia: Politics, Economics, and Culture in a Shattered Community (Westview Press, Boulder, CO, 1995).

4 According to figures provided by Archbishop France Perko of Belgrade, in NIN, No. 2235, 29 October 1993, p. 30.

$5 \quad$ Süddeutsche Zeitung (Munich), 14 February 1995, p. 6.

ibid.; and Süddeutsche Zeitung, 12 October 1995, p. 8.

Večernji list (Zagreb), 12 October 1995, p. 9.

$8 \quad$ Neue Zürcher Zeitung, 13 February 1996, p. 7.

- Vjesnik (Zagreb), 21 February 1993, p. 12, trans. in FBIS (Foreign Broadcast Information Service), Daily Report (Eastern Europe), 29 March 1993, p. 70.

10 Jure Kristo, 'The Catholic Church in a time of crisis', in Ramet and Adamovich (eds.), Beyond Yugoslavia ..., p. 444.

ibid., pp. 441-2.

See Obzor (Zagreb), 22 May 1995, pp. 16-9.

Slobodna Dalmacija (Split), 15 January 1995, p. 9, trans. in FBIS, Daily Report (Eastern Europe), 8 February 1995, p. 42; and Vjesnik, 15 June 1993, p. 3.

14 Danas, 4 October 1994, pp. 24-26, trans. into German under the title 'Zum Verhältnis von katholischer Kirche, Staat und Gesellschaft in Kroatien', in Südosteuropa, vol. 44, nos. 1-2, January-February 1995, p. 105.

15 Kana (Zagreb), March 1992, p. 37; and Novi Vjesnik (Zagreb), 28 September 1992, p. 4A.

16 Slobodna Dalmacija, 29 September 1994, p. 11.

17 Glas Slavonije (Osijek), 8 June 1994, p. 26.

18 Globus (Zagreb), 30 June 1995, p. 11.

14 Borba (Belgrade), 17 February 1993, p. 8, trans. in FBIS, Daily Report (Eastern Europe), 12 March 1993, pp. 59-60.

21) Feral Tribune (Split), 7 November 1994, as summarised in FBIS, Daily Report (Eastern Europe), 28 November 1994, p. 53.

21 Borba, 17 February 1993, p. 8, trans. in FBIS, Daily Report (Eastern Europe), 12 March 1993 , p. 60.

${ }^{22}$ Feral Tribune, 7 November 1994, as summarised in FBIS, Daily Report (Eastern Europe), 28 November 1994, p. 53.

23. HINA (Zagreb), 21 February 1995, in BBC Summary of World Broadcasts, 23 February 1995; HINA, 22 February 1995, in BBC Summary of World Broadcasts, 24 February 1995; and Vreme International (Belgrade), 27 February 1995, p. 4.

24 Vjesnik, 12 July 1993, p. 2; and Slobodna Dalmacija, 19 October 1994, p. 32.

25 Bishop Djuro Kokša of Zagreb, in December 1993, as cited in Wolf Oschlies, 'Zur politischen Rolle orthodoxer Kirchen auf dem Balkan', Südost Europa, vol. 42, no. 10, 1993, p. 591.

26 According to Živko Kustić, director of the Catholic Information Agency for Croatia and former editor of Glas koncila. See Živko Kustić, 'Predstavnici vlasti odsad ce morati računati s mišljenjem crkve!', Globus, 9 December 1994, p. 7.

27 Živko Kustić, Cak da se i neka satanistička skupina u Hrvatskoj ..., Globus, 30 June 1995, p. 12.

28 See ibid.

29 Večernji list, 1 April 1995, p. 7.

30 Novi list (Rijeka), as summarised in Balkan News \& East European Report (Athens), 4-10 June 1995, p. 2.

31 Quoted in ibid.

32 Both polls were reported in Globus, 23 September 1994, p. 11. For more about Cardinal 
Šeper, see Šeper: Gradja va životopis (Nadbiskupski duhovni stol, Zagreb, 1982).

33 Tanjug, 27 April 1992, in BBC Summary of World Broadcasts, 30 April 1992.

${ }^{34}$ See the cover-story interview with Archbishop Vinko Puljić, Arena (Zagreb), 19 November 1994, pp. 12-15.

35 See, for example, Novi Danas (Zagreb), 24 August 1992, p. 4.

${ }^{36}$ Tanjug, 6 July 1993, in BBC Summary of World Broadcasts, 9 July 1993; Oslobodjenje (Sarajevo), 1st English ed. (Sarajevo/Washington D.C.), April 1994, p. 7; and Reuters World Service, 6 September 1994, on Nexis Research Data.

${ }^{37}$ Reuters, 27 December 1993, on Nexis.

38 For documentation, see Globus, 1 April 1994, pp. 12-13, trans. in FBIS, Daily Report (Eastern Europe), 5 May 1994, p. 31.

39 Slobodna Dalmacija, 28 January 1995, p. 5.

40 Quoted in HINA, 18 May 1995, in BBC Summary of World Broadcasts, 19 May 1995.

${ }^{41}$ Večernji list, 25 March 1992, p. 35.

${ }^{42}$ Glas Istre (Pula), 11 June 1994, p. 14.

4.3 Večernji list, 1 October 1995, as summarised in Reuter News Service, 1 October 1995, on Nexis.

${ }_{44}$ Reuters News Service, 6 March 1996, on Nexis.

45 The Toronto Star, 20 May 1995, p. A26; and HINA, 20 May 1995, in BBC Summary of World Broadcasts, 22 May 1995.

46 National Catholic Reporter, 19 May 1995, p. 11.

47 AFP (Paris), 19 May 1995, on Nexis.

48 Reuters World Service, 28 May 1995, on Nexis; and Reuters World Service, 3 June 1995, on Nexis. Regarding Komarica, see also Die Welt (Bonn), 23 May 1995, p. 5; and Slobodna Dalmacija, 24 May 1995, p. 2, and 6 June 1995, p. 2.

49 Daily Telegraph (London), 14 February 1995, p. 20.

50 Slobodna Dalmacija, 3 June 1995, p. 8.

s1 Quoted in HINA, 22 August 1995, in BBC Monitoring Service: Eastern Europe, 23 August 1995.

52 Reuters News Service, 1 October 1995, on Nexis; and Financial Times, 2 October 1995, p. 3.

53 Puljić, in interview with Oslobodjenje, European weekly ed. (Sarajevo/Ljubljana), 22-9 June 1995, p. 6.

${ }_{54}$ Tanjug, 24 September 1992, in BBC Summary of World Broadcasts, 26 September 1992.

55 'Serbian and Russian patriarchs and Croatian cardinal appeal for peace', in Tanjug, 17 May 1994, in South Slav Journal, vol. 15, no. 1-2, Spring-Summer 1992, pp. 112-3.

56 Süddeutsche Zeitung, 31 December 1994-1 January 1995, p. 6.

57 Quoted in Paul Mojzes, 'The religiosity of Radovan Karadžić', Religion in Eastern Europe, vol. 15, no. 4, August 1995, p. 21.

58 Reuters, 31 January 1992, on Nexis. See also Veritas (Zagreb), March 1992, p. 16. For evidence of the Serbs' continued hostility toward Stepinac see Evropske novosti (Belgrade/ Frankfurt), 1 February 1996, p. 21. For a recent Croatian discussion of Stepinac see Državnost (Zagreb), 9 February 1996, p. 19.

s9 For documentation, see Sabrina Petra Ramet, Balkan Babel: The Disintegration of Yugoslavia from the Death of Tito to the Ethnic War, 2nd ed. (Westview Press, Boulder, CO, 1996), chapter 7.

60 Reported in Tanjug, 27 December 1995, in BBC Monitoring Service, 1 January 1996, on Nexis.

${ }^{61}$ Globus, 10 May 1996, pp. 2-4.

62 ibid., 22 September 1995, p. 11.

6. ibid., 3 November 1995, p. 4, trans. in FBIS, Daily Report (Eastern Europe), 6 November 1995, pp. 49-50.

64 See, for example, HINA, 15 November 1995, in BBC Monitoring Service: Eastern Europe, 17 November 1995. 
65 Globus, 10 May 1996, p. 3.

${ }_{66}$ See, for example, the Christian People's Party's expressions of satisfaction with the outcome of elections they lost in 1992, in Novi Vjesnik, 5 September 1992, p. 5A.

67 Državnost, 15 March 1996, p. 1.

68 New York Times, 9 September 1994, p. A7.

${ }^{69}$ Quoted in New York Times, 11 September 1994, p. 9. 